\title{
Pro-inflammatory Interlekin-33 induces dichotomic effects on cell proliferation in normal gastric
}

\section{epithelium and gastric cancer}

Laura Francesca Pisani ${ }^{a}, G$ Gian Eugenio Tontini ${ }^{b c}$, Carmine Gentile $^{b}$, Beatrice Marinoni ${ }^{b}$, Isabella Teani ${ }^{b}$, Nicoletta Nandi ${ }^{b}$, Pasquale $\mathrm{Creo}^{\mathrm{a}}$, Emanuele Asti ${ }^{\mathrm{ab}}$, Luigi Bonavina ${ }^{\mathrm{ab}}$, Maurizio Vecchi ${ }^{\mathrm{cd}}$, Luca Pastorelli ${ }^{\mathrm{f}}$.

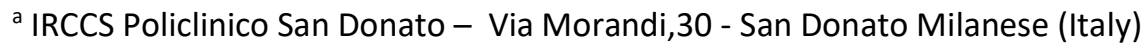

${ }^{b}$ Università degli Studi di Milano - Department of Biomedical Science for Health - Via Mangiagalli, 31 Milano (Italy)

' IRCCS Ca' Granda Ospedale Maggiore Policlinico di Milano - Via Francesco Sforza, 28 - Milano (Italy)

d Università degli Studi di Milano - Department of Pathophysiology and Trasplantation - Via Francesco Sforza, 35 - Milano (Italy)

e ASST Santi Paolo e Carlo - Via Di Rudinì, 8 - Milano (Italy)

${ }^{f}$ Università degli Studi di Milano - School of Medicine Ospedale San Paolo - Department of Health Sciences

- Via Di Rudinì, 8 - Milano (Italy)

${ }^{*}$ Corresponding author

Luca Pastorelli, MD, PhD

ASST Santi Paolo e Carlo

Via Di Rudinì, 8 - Milano (Italy)

Phone: +390252774683

e-mail: luca.pastorelli@unimi.it

\begin{abstract}
Background: Interleukin (IL)-33 is a member of interleukin (IL)-1 family of cytokines which has been linked to the development of inflammatory conditions and cancer in the gastrointestinal tract. This study is designed to investigate whether IL-33 has direct effect on human gastric epithelial cells (GES-1) and on
\end{abstract}


human gastric adenocarcinoma cell line (AGS) and gastric carcinoma cell line ( $\mathrm{NCl}-\mathrm{N} 87)$, assessing its role in regulation of cell proliferation and cell cycle, apoptosis and necrosis. Cell cycle regulation was also determined in ex vivo gastric cancer samples obtained during endoscopy and surgical procedures. Methods: cell lines and tissue samples underwent stimulation with rhlL-33. Proliferation was assessed by XTT and CFSE assay, we also evaluated apoptosis by Caspase 3/8 Activity assay and Annexin V assays. Cell cycle were analyzed by means of Propidium lodine assay and gene expression regulation was assessed by RT-PCR Profiling. Results: we found that IL-33 has an antiproliferative and proapoptotic effect on cancer cell line, while it can stimulate proliferation and reduce apoptosis in normal epithelial cell line. These effects are also confirmed by the analysis of cell cycle gene expression which showed a reduced expression of proproliferative genes in cancer cells, in particular genes involved in G0/G1 and G2/M checkpoint. These results are confirmed by the gene expression analysis on surgical and bioptic specimens. Conclusions: the aforementioned results indicate that IL-33 may be involved in cell proliferation in an environment- and cell type-dependent fashion.

Keywords: interleukin-33; gastric epithelium; proliferation; apoptosis; cell cycle; gastric cancer

\section{Introduction}

Gastric cancer is a leading cause of cancer-related deaths and is the fourth most common type of cancer in the world (1). The overall survival at 5-years of gastric cancer patients is only about $20 \%$ (2). Major risks for the development of gastric cancer are Helicobacter pylori infections, dietary factors and chronic gastritis (2).

The development of gastric cancer is a complex, multistep process involving multiple alterations in oncogenes, tumor suppressor genes, DNA repair genes, cell cycle regulators, and signaling molecules; thus, the pathways that lead to the transformation towards gastric cancer still need to be fully dissected $(3,4)$. Indeed, chronic inflammation plays a major role and pro-inflammatory cytokines appear to promote 
progression from gastritis to cancer; in particular, interleukin (IL)-1 family members, such as IL-1 $\beta$ and IL-18 have been shown to induce gastric cancerogenesis in animal models $(5,6)$.

IL-33 was identified as a new member of the IL-1 cytokine family and exerts its biological effects through the binding of its receptor, ST2, also known as IL-1 receptor-like 1 (IL1RL1), belonging to the Toll-IL-1 Receptor (TIR) superfamily $(5,7)$. IL-33 appears to be a cytokine with dual function, acting both as a traditional cytokine and as an intracellular nuclear factor with transcriptional regulatory properties and is involved in Gastrointestinal (GI) tract epithelial repair and restitution, and to promote mucosal healing (8, 9). IL-33 is broadly expressed in many tissues, but its expression appears to be restricted by cell type (5). Expression analysis of human and mouse cDNA libraries revealed high expression of IL-33 mRNA in barrier epithelia within organs/tissues in direct contact with the external environment, including the skin, airway, and gut epithelia, suggesting a possible role of this cytokine in early immune responses against invasive pathogens (5). At the cellular level IL-33 is predominantly present in stromal cells including fibroblasts, smooth muscle cells, endothelial and epithelial cells (10) and also in restricted population of hematopoietic cells, such as macrophages $(5,11)$.

Moreover, several studies show that normal mice injected with recombinant IL-33 develop a marked epithelial cell hyperplasia throughout the whole gastrointestinal tracts, features of spasmolytic polypeptide-expressing metaplasia in the stomach, together with infiltration into the lamina propria of eosinophils and mononuclear cells and sustained chronic Th2-driven inflammation (12-14).

The role of IL-33 in neoplasia has been poorly investigated but different studies reported both pro- and anti-tumorigenic functions (17). It has been hypothesized that IL-33 has pro-tumorigenic function in cancer cell lines inducing an increase in invasion, migration $(3,18)$ and chemoresistance $(19)$. In vivo, the protein seems to be less abundant in gastric tumor tissues than in surrounding normal tissue and it did not correlate to patients prognosis (20). These contrasting results suggest that the role of IL-33 in cancer development and growth is still to be clarified. In order to unravel some of these aspects we investigated whether IL-33 has effects on cell cycle and apoptosis in in vitro and ex vivo settings. 


\section{Materials and Methods}

\section{Cell lines and treatments}

Human gastric epithelial cells GES-1 cell line (Courtesy of Prof. Hong Cai Beijing Cancer Hospital, China), was cultured in RPMI-1640 (Sigma-Aldrich, Italy) supplemented with 10\% Fetal Bovine Serum (FBS), 1\% antibiotic solution $\left(100 \mathrm{U} / \mathrm{ml}\right.$ penicillin, $100 \mathrm{mg} / \mathrm{ml}$ streptomycin) at $37^{\circ} \mathrm{C}$ in a $5 \% \mathrm{CO}_{2}$ humidified atmosphere. Gastric adenocarcinoma cell line AGS (ATCC ${ }^{\circledR}$ CRL-1739 ${ }^{\mathrm{TM}}$ ) was cultured in F12 nutrient mix, Kaighn's Modification (Life Technology, Italy) and NCI-N87 [N87] (ATCC ${ }^{\circledR}$ CRL5822 $^{\text {TM }}$ ) was cultured in RPMI1640 Medium (Sigma-Aldrich, Italy) supplemented with 10\% FBS and 1\% antibiotic solution (100U/ml penicillin, $100 \mathrm{mg} / \mathrm{ml}$ streptomycin) at $37^{\circ} \mathrm{C}$ in a $5 \% \mathrm{CO}_{2}$ humidified atmosphere. $\mathrm{NCl}-\mathrm{N} 87$ cell line was used in these paper in order to confirm data obtained in AGS and clarify the not-cell specific effect of IL-33.

Cells were plated at $2.5 * 10^{5} / \mathrm{ml}$; after 2 days the cells reached $70 \%$ confluence and were used for the treatments. Cells were challenged with growing concentrations of recombinant human IL-33 (Alexis, Vinci Biochem, Italy) at $37^{\circ} \mathrm{C}$, for the incubation times indicated in the figure legends; rhIL-33 were suspended in sterile water and then diluted in complete medium specific for each cell line and added to cells to reach different final concentrations $(0.1 \mathrm{ng} / \mathrm{ml}, 1 \mathrm{ng} / \mathrm{ml}$ and $10 \mathrm{ng} / \mathrm{ml})$. In the control groups, cells were incubated with the same amount of complete medium without rhIL-33.

\section{Wound healing}

GES-1, AGS and NCl-N87 were grown to confluence in $\mu$-Dish $35 \mathrm{~mm}$, low (Ibidi, Germany). The biocompatible silicone insert allows cells to grow in two separate chambers making a gap of $500 \mu m \pm$ $50 \mu \mathrm{m}$. Medium was replaced by complete medium and medium with rhIL-33 (0h time point). Images were taken at $0,6 \mathrm{~h}$ and $24 \mathrm{~h}$ and cell migration distance was determined by subtracting values obtained at $0 \mathrm{~h}$ from each time point. Migration distances were expressed as percentages over control values. 


\section{Evaluation of cell proliferation}

Cell proliferation was evaluated using XTT Cell Proliferation Assay Kit (ATCC, Italy) on $5^{*} 10^{5}$ cells/well. Cells were seeded in 96-well plates in triplicates in $100 \mu \mathrm{L}$ of complete medium 18 hours before stimulation. Then different concentrations of rhIL-33 were added to cells and incubated for 6 and 24 hours. Activated-XTT Solution was prepared adding $100 \mu \mathrm{L}$ of the Activation Reagent to $5.0 \mathrm{~mL}$ of the XTT Reagent. Fifty $\mu \mathrm{L}$ of the Activated-XTT Solution was added to each well and the plate was returned to the $\mathrm{CO}_{2}$ incubator for the optimized-assay incubation time. Formazan formation was evaluated recording absorbance at 450nm wavelength using a microplate reader (Victor 3; Perkin-Elmer, USA), and expressed as mean absorbance \pm SEM.

Cell proliferation rate was also determined using flow cytometric analysis with CellTrace ${ }^{\mathrm{TM}}$ CFSE Cell Proliferation Kit (Life Technologies, Italy). Each daughter cell inherits approximately half of the fluorescent dye from the parental cell, hence allowing the quantification of cell divisions by the progressive decrease of CFSE fluorescence at different time intervals. Cells were harvested by trypsin digestion, washed three times and resuspended in $2 \mathrm{ml}$ PBS. Two microliters of CFSE stock solution was applied to $1 \mathrm{ml}$ cells to get a final concentration of $10 \mu \mathrm{M}$. Cells were incubated for $10 \mathrm{~min}$ at $37^{\circ} \mathrm{C}$. The staining was quenched by the addition of 5-volumes of ice-cold complete medium and incubated for $5 \mathrm{~min}$ in ice. Cells were washed two times and resuspended in complete medium with different rhIL-33 concentrations and further cultured up to 4,6 or 9 days.

\section{Cell cycle analysis by propidium-iodine (PI) staining}

Cells were trypsinized and washed once in PBS to remove residual serum and trypsin. Cell number per sample should be $1.5 \times 10^{6}$ cells. Cells were resuspended in cold $70 \%$ ethanol drop by drop while vortexing and fixed for 30 minutes in ice. Cells were then spinned at $850 \mathrm{~g}, 5 \mathrm{~min}, 4^{\circ} \mathrm{C}$, washed once in PBS, spinned at at $850 \mathrm{~g}, 5 \mathrm{~min}, 4^{\circ} \mathrm{C}$ and resuspend in PBS added with $1 \%$ Bovine Serum Albumin (BSA), spinned at $850 \mathrm{~g}, 5$ min, $4^{\circ} \mathrm{C}$ and resuspend in $500 \mu \mathrm{l}$ of PBS with $1 \%$ BSA and $0.1 \%$ Tween. 
Cells were then incubated for $15 \mathrm{~min}$ with RNAse A followed by the addition of $10 \mu$ l of Propidium lodine. Cell cycle analysis was performed by flow cytometer (PerkinElmer, Italy).

\section{Analysis of cell cycle by $\mathrm{RT}^{2}$ Profiler PCR Array for Cell Cycle}

Human Cell Cycle RT2 Profiler PCR Array (PAHS-0820, SABiosciences, Qiagen, Italy) was used to evaluate the expression of 84 specific genes related to cell cycle. After 24 hours of culture with rhlL-33 (10ng/ml) and without any challenge, total RNA was isolated using the miRNeasy Mini kit (Qiagen, Italy) according to the manufacturer's instructions. cDNA was synthesized from 500 ng of the total RNA using the RT2 First Strand Kit (Qiagen, Italy), which includes the additional removal of genomic DNA from the RNA sample and a specific control of reverse transcription. After all control tests, the samples were analysed using the RT2 Profiler PCR Array. Altogether, 84 different genes were simultaneously amplified in the sample. A melting curve analysis was performed to verify that the product consisted of a single amplicon. PCR arrays were performed in 96-well plates on a StepOne Plus instrument (Applied Biosystems, Italy). Briefly, the reaction

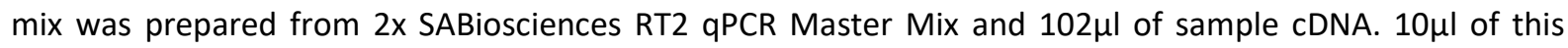
mixture was added into each well of the PCR Array. The thresholds and baselines were set according to the manufacturer's instructions and data were analysed using software supplied by Qiagen (http://www.sabiosciences.com/pcr/arrayanalysis.php). The fold change in gene expression compared to unstimulated control was calculated using the $\Delta \Delta \mathrm{Ct}$ method. A more than 1.5 fold change in gene expression compared to unstimulated control was considered as the up- or downregulation of a specific gene expression. The gene pathway modified by IL-33 was reconstructed by IPA Software (SABiosciences, Qiagen, Italy). The genes differentially expressed in the two cell lines have been tested by qRT-PCR.

\section{Evaluation of caspases-3 and caspase-7 activities}

Following $6 \mathrm{~h}$ and $24 \mathrm{~h}$ treatments cells were subjected to Caspase 3/7 activities measurement with CaspaseGlo assay kit (Promega, Italy). Briefly, the plates containing cells were removed from the incubator and allowed to equilibrate to room temperature for 30 minutes. $100 \mu$ l of Caspase-Glo reagent was added to 
each well, the content of well was gently mixed with a plate shaker at 300-500 rpm for 30 seconds. The plate was then incubated at room temperature for 2 hours. The luminescence of each sample was measured in a plate-reading luminometer (Victor 3; Perkin-Elmer, USA) with parameters of 1 minute lag time and 0.5 second/well read time. The experiments were performed in triplicate and repeated on three separately-initiated cultures.

\section{Annexin V Apoptosis Detection}

Cells were treated for 6 and 24 hours and at each time point they were subjected to Annexin V-FITC Apoptosis Detection kit (Enzo Life Science, Italy) to detect necrosis and to discriminate apoptotic cells by counterstaining with Propidium iodide using flow cytometry. After each treatment, $5^{*} 10^{5}$ cells $/ \mathrm{ml}$ were washed in PBS and resuspended in $195 \mu \mathrm{l}$ of Binding Buffer added with $5 \mu$ l of Annexin V-FITC and incubated for $10 \mathrm{~min}$ at RT. Then cells were washed twice with PBS and resuspended in 190 $\mu$ l of Binding Buffer adding $10 \mu \mathrm{l}$ of Propidium lodide $(20 \mu \mathrm{g} / \mathrm{ml})$. Number of apoptotic cells was determined by flow cytometer (PerkinElmer, Italy).

\section{Gastric tissue sample}

Human gastric tissue was collected by the Endoscopy Unit staff and by Surgery Unit at IRCCS Policlinico San Donato. Endoscopists provided biopsy samples of gastric mucosa which were classified as Normal, Gastritis Helicobacter pylori negative at histology and Gastric Adenocarcinoma after pathologist evaluation. Biopsies were immediately frozen in liquid nitrogen for further analysis. Surgical samples were collected from patients undergoing surgical procedure for gastric cancer removal. Full thickness samples were collected after resection from neoplastic area and non-neoplastic one and placed in cold PBS with $1 \%$ antibiotic solution $\left(100 \mathrm{U} / \mathrm{ml}\right.$ penicillin, $100 \mathrm{mg} / \mathrm{ml}$ streptomycin). Samples were washed in PBS, cut in $0.5 \mathrm{~cm}^{3}$ fragments and cultured in Dulbecco's Modified Eagle Medium (DMEM) supplemented with 10\% FBS, 1\% antibiotic solution $\left(100 \mathrm{U} / \mathrm{ml}\right.$ penicillin, $100 \mathrm{mg} / \mathrm{ml}$ streptomycin) at $37^{\circ} \mathrm{C}$ in a $5 \% \mathrm{CO}_{2}$ humidified atmosphere. Samples from cancer and healthy tissue were randomly assigned to be challenged with rhIL-33 
$(10 \mathrm{ng} / \mathrm{ml})$ or without challenge for $48 \mathrm{~h}$. After the treatment sample were frozen in liquid nitrogen for further analysis.

\section{RNA extraction, RT and RealTime PCR}

Total RNA samples were isolated from cells under various culture conditions by the use of a RNeasy kit (Qiagen, Italy), while total RNA was isolated from tissue samples by means of TRIzol ${ }^{\circledR}$ reagent (Life Technologies, Italy) following manufacturer's instructions.

One $\mu \mathrm{g}$ of total RNA from cells or tissues were subjected to DNase treatment (ThermoScientific, Italy) and then reverse transcribed using Oligo $(\mathrm{dT})_{18}$ primers and RevertAid H Minus First Strand cDNA Synthesis Kit (ThermoScientific, Italy). These cDNA preparations were subjected to quantitative RealTime-PCR using Maxima SYBR Green qPCR Master Mix (Thermo Scientific, Italy)using specific target gene primers (Table 2), normalized to Human Glyceraldehyde 3-phosphate dehydrogenase (GAPDH) and ribosomal protein S14 and reported as relative-fold-change among groups, with baseline control set at 1 .

\section{Statistical analysis}

Statistical analysis was performed by GraphPad Prism 7 (GraphPad software, USA) using the appropriate statistical tests according to underlying distribution of data, with $p \leq 0.05$ considered statistically significant.

\section{Ethical committee and Informed Consent Statement}

The research was carried out according to The Code of Ethics of the World Medical Association Declaration of Helsinki. The study protocol has been approved by the local Ethics Committee ASL Milano 2 (protocol n.2725-2012). All patients enrolled have been informed about the study, and a written informed consent for the research use of samples was obtained before undergoing endoscopy or surgery. 


\section{Results}

\section{IL-33 expression is increased in chronic gastritis}

Given the fact that IL-33 was shown to be overexpressed during chronic inflammation, we evaluate its expression gastric biopsies from patients who underwent EGDS procedures. Biopsies were collected and classified in Normal (HC; N=48), Gastritis H.pylori negative (G Hp-; N=21) and Gastritis H.pylori positive (G $\mathrm{Hp}+$; $\mathrm{N}=34$ ) (Table 1). Figure 1 showed that IL-33 is overexpressed in gastritis samples H.pylori negative (HC $0.15 \pm 0.03$ vs $\mathrm{G} \mathrm{Hp}-1.75 \pm 0.61 ; p<0.05)$ and even more in H.pylori positive gastritis ( $\mathrm{HC} 0.15 \pm 0.03$ vs $\mathrm{G} \mathrm{Hp}+$ $2.26 \pm 0.74 ; p<0.05)$.

\section{$\underline{\text { IL-33 differentially modulates gastric cell proliferation }}$}

IL-33 treatment exerted opposite effects on the different cell lines considered. The gastric cancer AGS cell line proliferation was reduced after IL-33 exposure, while normal gastric GES-1 cell line proliferation was induced at the same experimental conditions.

More in details, the XTT proliferation assay on GES-1 cells showed an increase in proliferation 24h of treatment with rhlL-33 $(0.1 \mathrm{ng} / \mathrm{ml} 2.61 \pm 0.03 ; \mathrm{p}<0.05$ and $1 \mathrm{ng} / \mathrm{ml} 2.61 \pm 0.25 ; \mathrm{p}<0.05$ and $10 \mathrm{ng} / \mathrm{ml} 2.75 \pm 0.04$; $p<0.001$ ) (Fig.2a).

The proliferative effect was confirmed by the scratch assays, where wound closure was accelerated in a dose-dependent fashion with a concentration of $10 \mathrm{ng} / \mathrm{ml}$ at 6 hours ( $\operatorname{ctrl} 2.76 \% \pm 2.0 \mathrm{vs}$. $10 \mathrm{ng} / \mathrm{ml} 6.17 \% \pm 1.9$; p<0.05) (Fig.2c) and 24 hours timepoints (ctrl 15.67\% \pm 5.2 vs. 10ng/ml 26.93\% $\pm 2.35 ; p<0.05$ ) (Fig. 2 c).

CFSE assay showed a trend towards an increased proliferation in IL-33 stimulated GES-1 with a doseresponse correlation, but the data did not reach a statistical significance (Fig. 2e).

Conversely, the XTT proliferation assay on AGS cells showed a reduction of proliferation at $24 \mathrm{~h}$ of treatment with rhlL-33 $(0.1 \mathrm{ng} / \mathrm{ml} 1.76 \pm 0.17 ; \mathrm{p}<0.05 ; 1 \mathrm{ng} / \mathrm{ml} 1.31 \pm 0.04 ; \mathrm{p}<0.05$ and $10 \mathrm{ng} / \mathrm{ml} 1.12 \pm 0.05$; p<0.05) (Fig. 2b).

To confirm that IL-33 could reduce AGS replication, we performed a scratch assay; wound closure was delayed when IL-33 was present, in a dose-dependent manner, starting from 6 hours, with IL-33 
concentrations of $1 \mathrm{ng} / \mathrm{ml}$ and $10 \mathrm{ng} / \mathrm{ml}$ (ctrl $34.54 \%$ vs. $1 \mathrm{ng} / \mathrm{ml} 3.89 \% \mathrm{p}<0.05 ; \operatorname{ctrl} 34.54 \% \mathrm{vs.} 10 \mathrm{ng} / \mathrm{ml} 2.55 \%$ p<0.05) (Fig. 2d).

Also, the CFSE assay showed a trend towards an inhibitory effect of IL-33 on AGS (Fig. 2f) in a dosedependent manner, but the data did not reach a statistical significance.

In order to assess whether or not IL-33 inhibitory effect on cell replication was specific to the AGS cell line we repeated the experiments on a different gastric cancer cell line, NCI-N87; with the XXT proliferation assay, the same inhibitory activity was observed in NCl-N87 cells where proliferation was reduced at $24 \mathrm{~h}$ treatment $(0.1 \mathrm{ng} / \mathrm{ml} 2.41 \pm 0.01 ; \mathrm{p}<0.05 ; 1 \mathrm{ng} / \mathrm{ml} 2.49 \pm 0.043 \mathrm{p}<0.05$ and $10 \mathrm{ng} / \mathrm{ml} 2.43 \pm 0.01 ; \mathrm{p}<0.05)$ (Supplementary Fig. 1a). Similarly, wound closure in $\mathrm{NCl}-\mathrm{N} 87$ was delayed when the $1 \mathrm{ng} / \mathrm{ml}$ and $10 \mathrm{ng} / \mathrm{ml}$ of rhIL-33 was present after 24 hours treatment ((Supplementary Fig. 1b), whereas CFSE assay showed a dosedependent reduced replication in NCI-N87 cells, that, however, was not statistically significant (Supplementary Fig. 1c).

\section{$\underline{\text { IL-33 induces apoptosis in gastric cancer cell line, but not in non-neoplastic cells }}$}

Apoptosis is another parameter evaluated in this study. Our experiments showed that IL-33 had different effects on different cell lines. In GES-1 evaluation of caspase-3 and caspase-7 activities did not show any variation in apoptosis (Fig. 3a). Annexin V/Propidium lodine assay showed a reduction in Annexin $\mathrm{V}$ after 6 (ctrl $66.0 \% \pm 29.5$ vs. $1 \mathrm{ng} / \mathrm{ml} 24.7 \% \pm 13.2 ; \mathrm{p}<0.05$ ) and 24 hours of incubation with IL-33 (ctrl $69.0 \% \pm 28.8$ vs. $0.1 \mathrm{ng} / \mathrm{ml} 16 \% \pm 3.5 ; \mathrm{p}<0.05 ; \operatorname{ctrl} 69.0 \% \pm 28.8$ vs. $1 \mathrm{ng} / \mathrm{ml} 13.7 \% \pm 1.12 ; \mathrm{p}<0.05$, respectively) (Fig.3c) indicating that IL-33 could reduce apoptosis in the normal gastric epithelium cell line.

In AGS evaluation of caspase-3 and caspase-7 activities showed an increase in apoptosis at $10 \mathrm{ng} / \mathrm{mL}$ and $1 \mathrm{ng} / \mathrm{ml}$ of IL-33 after 6 h treatment (ctrl $8510 \pm 841 \mathrm{vs.} 10 \mathrm{ng} / \mathrm{mL} 10214 \pm 496$ and ctrl $8510 \pm 841 \mathrm{vs.} 1 \mathrm{ng} / \mathrm{mL}$ 12338 $\pm 739 ;$ p $<0.05$ ) (Fig.3b). This data is confirmed by the Annexin V/Propidium lodine assay, where IL-33 $10 \mathrm{ng} / \mathrm{ml}$ increased Annexin $\mathrm{V}$ at 6 hours treatment ( $\operatorname{ctrl} 8.0 \% \pm 11.3$ vs. $10 \mathrm{ng} / \mathrm{ml} 18.5 \% \pm 16.3 ; \mathrm{p}<0.05$ ) and with IL-33 $0.1 \mathrm{ng} / \mathrm{ml}$ at 24 hours treatment (ctrl $7.0 \% \pm 9.0$ vs. $0.1 \mathrm{ng} / \mathrm{ml} 16.0 \% \pm 14.1 ; p<0.05)$ (Fig. $3 \mathrm{~d}$ ). 
Confirmatory experiments on $\mathrm{NCl}-\mathrm{N} 87$, evaluating caspase-3 and caspase-7 activities did not show any variation in apoptosis (Supplementary Fig.2a), while Annexin V/Propidium lodine assay showed an increase in apoptosis at $0.1 \mathrm{ng} / \mathrm{mL}$ at 6 hours treatment (ctrl $13.4 \% \pm 1.3$ vs. $0.1 \mathrm{ng} / \mathrm{ml} 33.2 \% \pm 2.9 ; \mathrm{p}<0.05$ ) (Supplementary Fig.2b) indicating that IL-33 could induce apoptosis in cancer cell lines.

\section{$\underline{\text { IL-33 acts on cell cycle gene expression in gastric cell lines }}$}

In order to demonstrate the effect of IL-33 on the AGS and GES-1 cell cycle, we conducted a series of cytofluorometric analysis experiments after Propidium iodide staining with rhlL-33 stimulation. As shown in Figure 4a, in GES-1, IL-33 induces an increase in phase $S$ at the expense of the other two, perhaps for a block between S phase and G2 phase; in particular non-stimulated GES-1 vs. IL-33 treated cells exhibit a percentage of G0/G1 transition cells of $59.4 \%$ vs. $47.5 \%$, in phase S: $5.7 \%$ vs. $31.3 \%$, and in G2/M transition: 28.7\% vs. $17.8 \%$. In AGS IL-33 seems to have the opposite effect, in fact there is a block between phases G1/G0 and S, and the latter decreases considerably after treatment at $24 \mathrm{~h}$ that means that cells are not entering the S phase remaining in G1 phase; in particular non-stimulated AGS vs. IL-33 treated cells exhibit a percentage of G0/G1 transition cells: $49.9 \%$ vs. $59.9 \%$, in phase S: $26.9 \%$ vs. $7.1 \%$, and in G2/M transition: $19.4 \%$ vs. $26.7 \%$ (Fig.4b).

To explore further the potential molecular mechanisms underlying IL-33-mediated cell proliferation changes, we studied the expression of cell cycle. We compared GES-1 cells with AGS tumor cells, reporting the differential expression of six genes (Table 2). In particular, the cyclin C (CCNC), whose activation controls the transition G0/G1, and the cyclin E1 (CCNE1), whose activation promotes the G1/S transition, showed an increase of 6.11 and 6.04 times, respectively in AGS vs. GES-1 cells $(p<0.05)$. Cellular regulatory genes such as BRCA and CDKN1A interacting protein (BCCIP), cyclin B1 (CCNB1) and Karyopherin 2 (KPNA2) genes involved in G2/M transition and DNA damage and repair control points increased by $2.34,2.39$ and 3.05 times, respectively in AGS vs. GES-1 cells ( $p<0.05)$. The expression of Caspase 3 (CASP3) was increased by 24.08 times $(p<0.05)$ in AGS vs. GES-1 cells. Then cells were challenged for 24 hours with rhIL-33 $(10 \mathrm{ng} / \mathrm{ml})$ and we observed that in AGS the stimulation with rhIL-33 decreased the expression of the 
selected genes, in particular, CCNC and CCNE1 showed a decrease of 3.31 and 4.15 times, respectively $(p<0.001)$. BCCIP, CCNB1 decreased by 1.65 times $(p<0.05)$. The expression of CASP3 was more than halved by the treatment by 10.57 times $(p<0.05)$, suggesting IL-33 was promoting the initiation of the apoptotic cascade through the induction of caspase synthesis. In GES-1 the stimulation increased the expression of all the six genes considered but only KPNA1 reach a statistically significant modulation in comparison to untreated GES-1 cells (1.46 fold, $p<0.05)$.

\section{$\underline{\text { IL-33-stimulation of human gastric biopsies and surgical specimens modifies cell cycle gene expression }}$}

Before testing the cell cycle genes expression after the treatment with rhlL-33 on ex vivo samples we checked the expression of IL-33 and its receptor ST2 on biopsies collected from patients who underwent endoscopy and classified as Healthy Control (HC; N=48) and Gastric cancer patients (GC; N=16) (Table 1). Results show that IL-33 is downregulated in GC group vs. HC $(0.53 \pm 0.30 ; \mathrm{p}<0.001)$ (Fig.5a) while ST2L is upregulated in Gastric cancer patients (3.12 $\pm 2.30 ; p<0.05)$ (Fig.5b).

To further explore the potential molecular effect of IL-33 on ex vivo human gastric tissues we first determine the expression by RT-PCR of the six genes identified in cell line profiler in biopsies from normal gastric tissue, and cancer tissue coming from different patients (Table 1). Figure 6 shows that all the genes modulated in cell lines are overexpressed in gastric cancer samples $(p<0.05)$, only BCCIP, even if overexpressed, does not reach a statistical significance (Fig. 6c).

Then we performed the same analysis on surgical specimen from three patients (mean age $75 \pm 11$ ) with gastric cancer after stimulation with rh-IL-33 $(10 \mathrm{ng} / \mathrm{ml})$ for $48 \mathrm{~h}$. Samples defined Healthy (HC) and Gastric Cancer (GC) came from the same patient identifying with $\mathrm{HC}$ a region of stomach far from the region with confirmed gastric cancer. Figure 7 shows that all genes are overexpressed in GC samples vs HC tissue. In particular CASP3 after treatment with rhIL-33 is upregulated in HC $(3.07 \pm 1.04$ vs ctrl; $p<0.05)$ and downregulated in GC samples $(0.57 \pm 0.20$ vs ctrl; $p<0.05)$, showing an effect on induction of apoptosis ex vivo (Fig.7a). All the other genes expression is downregulated in GC samples after treatment with rhIL-33 (Fig.7b-f) suggesting a role of this cytokine in the reduction of neoplastic cells proliferation. In normal tissue 
CCNC and CCNE1 were upregulated after treatment with rhIL-33 suggesting a role in induction of the transition of cells through G0/G1 and G1/S checkpoints (Fig.7e-f).

\section{Discussion}

The persistence of long-standing chronic inflammation is known to be of paramount importance in the development of gastric cancer; still, the precise role of each molecule participating to the pro-inflammatory mileu in chronic gastritis has still to be dissected. Herein, we confirm that IL-33 is highly expressed in gastric mucosa during gastritis and we identify diverging effects of this molecule on normal and neoplastic gastric epithelium. In fact, the incubation with rhIL-33 of GES-1 results in a significant cell proliferation increase, with no changes in apoptosis rates. These results are consistent with the observations that exposure to IL33 causes histological changes in the lungs and GI tract, including epithelial cell hyperplasia and hypertrophy $(5)$ and also metaplasia $(4,14,21)$ and argue in favor of a role of IL-33 in the epithelial alterations preceding the neoplastic transformation.

By carrying out Real Time PCR and Western Blot, we have demonstrated the expression of the ST2 receptor in both cell lines (data not shown); this effect on proliferation of epithelial cells might be determined by direct action of IL-33 on the epithelial cells, given the expression of the ST2 receptor on the proliferating epithelium. Unlike GES-1, the administration of rhIL-33 to AGS tumor cells leads to a reduction in proliferation, which is accompanied by an intensification of apoptosis. Overall, these results are of great interest, as they propose a direct antitumor action of the cytokine.

It is not the first time that IL-33 demonstrates antitumor properties, but previous studies suggested that those effects could be mediated mostly by the influence of cytokine on the immune system activation (22). Moreover, while the stimulation of cell proliferation has been demonstrated on different immune (23), stromal (24), epithelial (25) cell lines, an anti-proliferative effect of IL-33 is relatively new in the literature. It has been found only in two cases: on non-neoplastic murine fibroblastic cell line in a study conducted by Tominaga et al. (26), and on neoplastic pancreatic cells in a recent work by Fang et al. (27) in which they found that IL-33 is able to suppress cell proliferation only on quiescent cells, while it stimulates replication 
on proliferating cells. IL-33 appears to exert its effect only on cells in G0 phase suggesting the cytokine acts through a block between G0/G1 phase, that could be mediated by the increase of cell cycle inhibitory regulatory proteins (28). These observations are partially transferable to the cell lines used in our study. In fact, it can be speculated that IL-33 acts with anti-proliferative and pro-apoptotic effect only on the quiescent AGS, thus determining a significant reduction in replication, which however remains higher than that of normal GES-1. Our cytofluorimetric analysis of the cell cycle is consistent with the hypothesis of a block in G0/G1 transition. This test demonstrates a significant reduction in the percentage of cells in $\mathrm{S}$ phase in AGS, suggesting a block upstream of $S$ phase, such as a block in $G 0 / G 1$. Also the reduction of the expression of Cyclin C (CCNC) gene, necessary, together with the cyclin dependent kinase 3 (Cdk3), for the entry of quiescent cells in the G1 phase (29), could be responsible for this effect. CCNC, in fact, forms a complex with the Rb protein and Cdk3, triggering its enzymatic activity. The latter, then, phosphorylates the $\mathrm{Rb}$ protein inactivating it, which is sufficient for the cell to re-enter the cell cycle (30); that is probably because the hyperphosphorylated isoform of pRb loses affinity for E2F transcription factors, leaving them free to promote cell cycle progression (31). Additional genes we focused on are those that showed variations in opposite directions in normal and neoplastic cells, reflecting the dichotomic effects of IL-33. In AGS cells, at baseline, these genes are expressed at much higher levels than in GES-1, as it can be expected in tumor cells, but treatment with rhIL-33 causes a significant decrease in the expression of each of them. This is consistent with the antiproliferative effect we observed on these cells. Whereas the reduction of CASP3 gene expression might be considered anti-apoptotic, it should not be forgotten that Caspases 3 and 7 demonstrated increased activity upon IL-33 administration, sufficient to support the proapoptotic effect of the cytokine. The reduction of CASP3 expression has instead an interesting implication in the effects on the cell cycle. In fact, Caspase 3 is also capable of cleaving p21 protein, repressor of the progression in the cell cycle, which acts on stimulation of the p53 protein, degrading the cyclin $B$, which is responsible for the G2/M transition. The same activity is performed by the BCCIP gene product, also downregulated in AGS. Consequently, the reduction of the expression of CASP3 and BCCIP would also result in a reduced degradation of p21 and consequently a greater inhibition of proliferation. Consistently, our 
results show the reduction of the mRNA of CCNB1, coding for cyclin B, target of p21. Data obtained on pancreatic cancer cells further support our results; in fact, pancreatic neoplastic cells show an increased expression of p53, p15 and p21, which are cell proliferation inhibitors (27). On the other hand, the expression of cell cycle progression-promoting genes, Cdk4 and Cdk2, decreased in pancreatic cells incubated with IL-33 (27). Cdk2 is the kinase that interacts with cyclin E, also downregulated in AGS, while Cdk4 binds to cyclin D, forming a further complex involved in the first phase $\mathrm{G} 1$ and potential site of the block of S phase in AGS. All these results prove to be coherent and complementary with ours and deserve further discussion

After having verified the expression of IL-33 and its receptor in gastric biopsies from healthy and gastric cancer patients, we evaluated the expression of the cell cycle candidate genes before and after stimulation with the cytokine and, as Kania et al. (32) and Sun et al. (33) reported, we observed that CASP3 expression was decreased in patients with gastric tumors compared to that in patients with normal gastric tissue. The prognostic value of some proteins of the CASP family in gastric cancer (GC) and in particular of CASP3 was associated to favorable clinicopathological features and a positive prognosis after curative surgery (34). The 5-year overall survival rates of gastric cancer patients with higher expression of CASP3 were $51.2 \%$ (35). From these evidence Caspase-3 may act as a tumor suppressor in human gastric cancer and data obtained by our ex vivo experiments shows that the effect of IL-33 on induction of CASP3 supports the potential role of IL-33 as anti-tumor factor. In gastric cancer, information about DNA copy number changes and gene expression changes showed differential gene expression between gastric tumor tissues and normal gastric tissues and the main genes are involved in basic functions such as the cell cycle, transcription, metabolism, signal transduction and DNA replication. CCNC is among the genes with reduced copy number and mRNA expression in gastric cancer vs. normal tissue (36). CCNC has been reported deleted in patients with acute lymphoblastic leukemia (37) supporting the possibility that the CCNC gene is closely linked to tumor suppressor genes. Our data showed that CCNC is downregulated in gastric cancer and also the treatment with rhIL-33 further reduced its expression. 
Overall, our in vitro results demonstrate different IL-33 effects depending on the cell line: pro-proliferative on healthy gastric epithelial cells and anti-proliferative and pro-apoptotic on neoplastic gastric epithelium. The analysis of the underlying gene expression patterns supports a role of IL-33 in regulating cell cycle and apoptosis in gastric cancer tissue. In conclusion, the involvement of specific cell cycle regulators and apoptosis in the mechanisms of neoplastic transformation of gastric epithelial cells clearly emerges from this work. The ability of IL-33 to affect their expression is also demonstrated, probably by binding to its receptor, expressed by both normal and neoplastic epithelial cells. The antitumor action of IL-33 that emerged from the in vitro study has important clinical relevance; in fact, it offers evidence to support a possible use of the cytokine in immunotherapy against gastric adenocarcinoma, a therapeutic field that is going through a phase of great dynamism (38). It could thus respond to the urgency of identifying new and more effective weapons against this neoplasm. In fact, in the Western countries the decrease in gastric adenocarcinoma mortality observed recently depends more on the reduction of the incidence than on the improvement of the treatment. Because of the difficulty of implementing screening programs in the West, gastric cancer is mainly diagnosed in the advanced stage, resulting in a negative prognosis (39). However, we must not forget that the opposite stimulating effects of proliferation observed on gastric epithelial cells could mean a pro-tumorigenic effect on the normal epithelium. Consequently, it is important to further dissect the molecular pathways involved in order to identify the correct targets for a possible therapeutic manipulation of the IL-33/ST2 axis.

\section{Author Contributions}

Conceptualization, Laura Francesca Pisani; Funding acquisition, Maurizio Vecchi and Luca Pastorelli; Investigation, Laura Francesca Pisani, Beatrice Marinoni, Isabella Teani, Nicoletta Nandi and Pasquale Creo; Resources, Laura Francesca Pisani, Gianeugenio Tontini, Carmine Gentile, Beatrice Marinoni and Emanuele Asti; Supervision, Luca Pastorelli; Writing - original draft, Laura Francesca Pisani; Writing - review \& editing, Luigi Bonavina, Maurizio Vecchi and Luca Pastorelli. 


\section{Conflicts of Interest}

None of the authors have any conflicts of interest related to this article to declare.

\section{Financial support}

This work was supported in part by the SIGE - Società Italiana di Gastroenterologia ed Endoscopia Digestiva

- Italian Society of Gastroenterology and Digestive Endoscopy Research Grant

\section{References}

1. Carcas LP. Gastric cancer review. J Carcinog. 2014;13:14.

2. Nagini S. Carcinoma of the stomach: A review of epidemiology, pathogenesis, molecular genetics and chemoprevention. World J Gastrointest Oncol. 2012;4(7):156-69.

3. Wasmer MH, Krebs P. The Role of IL-33-Dependent Inflammation in the Tumor Microenvironment. Front Immunol. 2016;7:682.

4. Petersen CP, Meyer AR, De Salvo C, Choi E, Schlegel C, Petersen A, et al. A signalling cascade of IL-33 to IL-13 regulates metaplasia in the mouse stomach. Gut. 2017.

5. Schmitz J, Owyang A, Oldham E, Song Y, Murphy E, McClanahan TK, et al. IL-33, an interleukin-1-like cytokine that signals via the IL-1 receptor-related protein ST2 and induces T helper type 2-associated cytokines. Immunity. 2005;23(5):479-90.

6. Tu S, Bhagat G, Cui G, Takaishi S, Kurt-Jones EA, Rickman B, et al. Overexpression of interleukin1 beta induces gastric inflammation and cancer and mobilizes myeloid-derived suppressor cells in mice. Cancer Cell. 2008;14(5):408-19.

7. Fagundes CT, Amaral FA, Souza AL, Vieira AT, Xu D, Liew FY, et al. ST2, an IL-1R family member, attenuates inflammation and lethality after intestinal ischemia and reperfusion. J Leukoc Biol. 2007;81(2):492-9.

8. Lopetuso LR, De Salvo C, Pastorelli L, Rana N, Senkfor HN, Petito V, et al. IL-33 promotes recovery from acute colitis by inducing miR-320 to stimulate epithelial restitution and repair. Proc Natl Acad Sci U S A. 2018;115(40):E9362-E70.

9. Monticelli LA, Osborne LC, Noti M, Tran SV, Zaiss DM, Artis D. IL-33 promotes an innate immune pathway of intestinal tissue protection dependent on amphiregulin-EGFR interactions. Proc Natl Acad Sci U S A. 2015;112(34):10762-7.

10. Miller AM. Role of IL-33 in inflammation and disease. J Inflamm (Lond). 2011;8(1):22.

11. Pastorelli L, Garg RR, Hoang SB, Spina L, Mattioli B, Scarpa M, et al. Epithelial-derived IL-33 and its receptor ST2 are dysregulated in ulcerative colitis and in experimental Th1/Th2 driven enteritis. Proc Natl Acad Sci U S A. 2010;107(17):8017-22.

12. Humphreys NE, Xu D, Hepworth MR, Liew FY, Grencis RK. IL-33, a potent inducer of adaptive immunity to intestinal nematodes. J Immunol. 2008;180(4):2443-9.

13. Neill DR, Wong SH, Bellosi A, Flynn RJ, Daly M, Langford TK, et al. Nuocytes represent a new innate effector leukocyte that mediates type-2 immunity. Nature. 2010;464(7293):1367-70.

14. De Salvo C, Pastorelli L, Petersen CP, Buttò LF, Buela KA, Omenetti S, et al. IL-33 triggers early eosinophil-dependent events leading to metaplasia in a chronic model of gastritis-prone mice. Gastroenterology. 2020.

15. da Silva EAW, da Silva NMJW, Rodrigues RR, Adad SJ, de Lima Pereira SA, Ribeiro BM, et al. Arginase-1 and Treg Profile Appear to Modulate Inflammatory Process in Patients with Chronic Gastritis:. Mediators Inflamm. 2019;2019:2536781. 
16. Buzzelli JN, Chalinor HV, Pavlic DI, Sutton P, Menheniott TR, Giraud AS, et al. IL33 Is a Stomach Alarmin That Initiates a Skewed Th2 Response to Injury and Infection. Cellular and Molecular Gastroenterology and Hepatology. 2015;1:203-21.

17. Lu B, Yang M, Wang Q. Interleukin-33 in tumorigenesis, tumor immune evasion, and cancer immunotherapy. J Mol Med (Berl). 2016;94(5):535-43.

18. Yu XX, Hu Z, Shen X, Dong LY, Zhou WZ, Hu WH. IL-33 Promotes Gastric Cancer Cell Invasion and Migration Via ST2-ERK1/2 Pathway. Dig Dis Sci. 2015;60(5):1265-72.

19. Ye XL, Zhao YR, Weng GB, Chen YC, Wei XN, Shao JP, et al. IL-33-induced JNK pathway activation confers gastric cancer chemotherapy resistance. Oncol Rep. 2015;33(6):2746-52.

20. Hu W, Li X, Li Q, Tan Y, Xu B, Xie Q, et al. Interleukin-33 Expression does not Correlate with Survival of Gastric Cancer Patients. Pathol Oncol Res. 2017;23(3):615-9.

21. Buzzelli JN, Chalinor HV, Pavlic DI, Sutton P, Menheniott TR, Giraud AS, et al. IL33 Is a Stomach Alarmin That Initiates a Skewed Th2 Response to Injury and Infection. Cell Mol Gastroenterol Hepatol. 2015;1(2):203-21.e3.

22. Gao X, Wang X, Yang Q, Zhao X, Wen W, Li G, et al. Tumoral expression of IL-33 inhibits tumor growth and modifies the tumor microenvironment through CD8+ $\mathrm{T}$ and NK cells. J Immunol. 2015;194(1):438-45.

23. Tong X, Barbour M, Hou K, Gao C, Cao S, Zheng J, et al. Interleukin-33 predicts poor prognosis and promotes ovarian cancer cell growth and metastasis through regulating ERK and JNK signaling pathways. Mol Oncol. 2016;10(1):113-25.

24. Bianchetti L, Marini MA, Isgrò M, Bellini A, Schmidt M, Mattoli S. IL-33 promotes the migration and proliferation of circulating fibrocytes from patients with allergen-exacerbated asthma. Biochem Biophys Res Commun. 2012;426(1):116-21.

25. Saluja R, Hawro T, Eberle J, Church MK, Maurer M. Interleukin-33 promotes the proliferation of mouse mast cells through ST2/MyD88 and p38 MAPK-dependent and Kit-independent pathways. J Biol Regul Homeost Agents. 2014;28(4):575-85.

26. Tominaga S, Tago K, Tsuda H, Komine M. Dual function of IL-33 on proliferation of NIH-3T3 cells. Cytokine. 2015;72(1):105-8.

27. Fang Y, Zhao L, Xiao H, Cook KM, Bai Q, Herrick EJ, et al. IL-33 acts as a foe to MIA PaCa-2 pancreatic cancer. Med Oncol. 2017;34(2):23.

28. Johnson DG, Walker CL. Cyclins and cell cycle checkpoints. Annu Rev Pharmacol Toxicol. 1999;39:295-312.

29. Sage J. Cyclin C makes an entry into the cell cycle. Dev Cell. 2004;6(5):607-8.

30. Sage J, Miller AL, Pérez-Mancera PA, Wysocki JM, Jacks T. Acute mutation of retinoblastoma gene function is sufficient for cell cycle re-entry. Nature. 2003;424(6945):223-8.

31. Ren S, Rollins BJ. Cyclin C/cdk3 promotes Rb-dependent G0 exit. Cell. 2004;117(2):239-51.

32. Kania J, Konturek SJ, Marlicz K, Hahn EG, Konturek PC. Expression of survivin and caspase-3 in gastric cancer. Dig Dis Sci. 2003;48(2):266-71.

33. Sun Y, Chen XY, Liu J, Cheng XX, Wang XW, Kong QY, et al. Differential caspase-3 expression in noncancerous, premalignant and cancer tissues of stomach and its clinical implication. Cancer Detect Prev. 2006;30(2):168-73.

34. Wang Z, Ni F, Yu F, Cui Z, Zhu X, Chen J. Prognostic significance of mRNA expression of CASPs in gastric cancer. Oncol Lett. 2019;18(5):4535-54.

35. Huang KH, Fang WL, Li AF, Liang PH, Wu CW, Shyr YM, et al. Caspase-3, a key apoptotic protein, as a prognostic marker in gastric cancer after curative surgery. Int J Surg. 2018;52:258-63.

36. Yang S, Jeung HC, Jeong HJ, Choi YH, Kim JE, Jung JJ, et al. Identification of genes with correlated patterns of variations in DNA copy number and gene expression level in gastric cancer. Genomics. 2007;89(4):451-9.

37. Li H, Lahti JM, Valentine M, Saito M, Reed SI, Look AT, et al. Molecular cloning and chromosomal localization of the human cyclin C (CCNC) and cyclin E (CCNE) genes: deletion of the CCNC gene in human tumors. Genomics. 1996;32(2):253-9. 
38. Schumacher TN, Schreiber RD. Neoantigens in cancer immunotherapy. Science. 2015;348(6230):6974.

39. Ferlay J, Soerjomataram I, Dikshit R, Eser S, Mathers C, Rebelo M, et al. Cancer incidence and mortality worldwide: sources, methods and major patterns in GLOBOCAN 2012. Int J Cancer. 2015;136(5):E359-86. 
Table 1: Demographic of patients enrolled for bioptic specimen collection

\begin{tabular}{|c|c|cc|c|}
\hline Group & N & Gender & $\mathbf{n}(\%)$ & Age (mean \pm SD) \\
\hline Healthy Controls & 48 & $\mathrm{~F}$ & $33(68.8)$ & $60.7 \pm 15.1$ \\
(HC) & & M & $15(31.3)$ & \\
\hline $\begin{array}{c}\text { Gastritis H.pylori negative } \\
\text { (G Hp-) }\end{array}$ & 21 & $\mathrm{~F}$ & $10(47.6)$ & $71.5 \pm 14.1$ \\
\hline $\begin{array}{c}\text { Gastritis H.pylori positive } \\
\text { (G Hp+) }\end{array}$ & 34 & $\mathrm{~F}$ & $21(61.8)$ & $66.2 \pm 18.5$ \\
\hline Gastric cancer & 16 & $\mathrm{~F}$ & $10(62.5)$ & $75.6 \pm 8.1$ \\
(GC) & & $\mathrm{M}$ & $6(37.5)$ & \\
\hline
\end{tabular}

Table 2: Cell cycle genes differentially regulated in GES-1 and AGS cells after rhIL-33 stimulation. Using GES1 as control cell line we selected a subset of genes that are differentially regulated between the two cell lines.

\begin{tabular}{|l|c|c|c|c|c|c|c|}
\hline \multirow{2}{*}{$\begin{array}{c}\text { Gene } \\
\text { Symbol }\end{array}$} & \multicolumn{4}{|c|}{ Fold change } & \multicolumn{3}{c|}{ p-value } \\
\cline { 2 - 9 } & GES-1 & GES-1 + rhIL-33 & AGS & AGS + rhIL-33 & GES-1 + rhIL-33 & AGS & AGS + rhIL-33 \\
\hline BCCIP & 1.000 & 1.453 & $\mathbf{2 . 3 9 5}$ & $\mathbf{1 . 6 4 9}$ & 0.281 & $\mathbf{0 . 0 0 2}$ & $\mathbf{0 . 0 1 9}$ \\
\hline CASP3 & 1.000 & 1.818 & $\mathbf{2 4 . 0 8 4}$ & $\mathbf{1 0 . 5 6 6}$ & 0.141 & $\mathbf{0 . 0 0 0 0 3}$ & $\mathbf{0 . 0 1 0}$ \\
\hline CCNB1 & 1.000 & 1.446 & $\mathbf{2 . 3 8 9}$ & $\mathbf{1 . 6 5 3}$ & 0.284 & $\mathbf{0 . 0 0 2}$ & $\mathbf{0 . 0 1 9}$ \\
\hline CCNC & 1.000 & 1.473 & $\mathbf{6 . 1 0 5}$ & $\mathbf{3 . 3 1 3}$ & 0.265 & 0.053 & $\mathbf{0 . 0 0 0 4}$ \\
\hline CCNE1 & 1.000 & 1.153 & $\mathbf{6 . 0 3 5}$ & $\mathbf{4 . 1 4 5}$ & 0.576 & $\mathbf{0 . 0 0 0 1}$ & $\mathbf{0 . 0 0 0 1}$ \\
\hline KPNA2 & 1.000 & 1.456 & $\mathbf{3 . 0 4 6}$ & 1.039 & $\mathbf{0 . 0 0 6}$ & $\mathbf{0 . 0 0 0 2}$ & 0.744 \\
\hline
\end{tabular}

Table 3: Primer pairs used for cDNA amplification of genes differentially expressed in the two cell lines.

\begin{tabular}{|c|c|c|}
\hline Gene & Forward & Revers \\
\hline human IL-33 & GACTCCTCCGAACACAGAGC & TGCTTGCTGTGTTCTTCCAC \\
\hline human ST2L & TTGCAAGGACAGCATCAAAG & GTCTGTGTTCCTGCCCAAAT \\
\hline human CASP3 & ACATCTCGGTCTGGTACAG & ACATCACGCATCAATTCCAC \\
\hline human KPNA2 & GTTGGCTCTCCTTGCAGTTC & GGGGTGCAGGATTCTTGTTG \\
\hline human BCCIP & GAACTCGCGGTCACAGTACT & CACATGCGCTGATCAGTAGG \\
\hline human CCNC & CTAGCCCAGCCTAGCAGAAA & ACTTCATGTAGTTTGCCCAGC \\
\hline human CCNE1 & CTCTTCTGTCTGTTGCAGCG & TTGCCCTGTTTGATGCCATC \\
\hline human CCNB1 & GGTTGTTGCAGGAGACCATG & AACATGGCAGTGACACCAAC \\
\hline human GAPDH & CCATCACCATCTTCCAGGAG & CCTGCTTCACCACCTTCTTG \\
\hline human S14 & GTGTGACTGGTGGGATGAAGG & TTGATGTGTAGGGCGGTGATAC \\
\hline
\end{tabular}




\section{Figure Legends}

Figure 1: Expression of IL-33 in gastric biopsies: Data are shown as mean \pm sd. HC: Healthy Controls; GHp-: Gastritis H.pylori negative; GHp+: Gastritis H.pylori positive. * $p<0.05$.

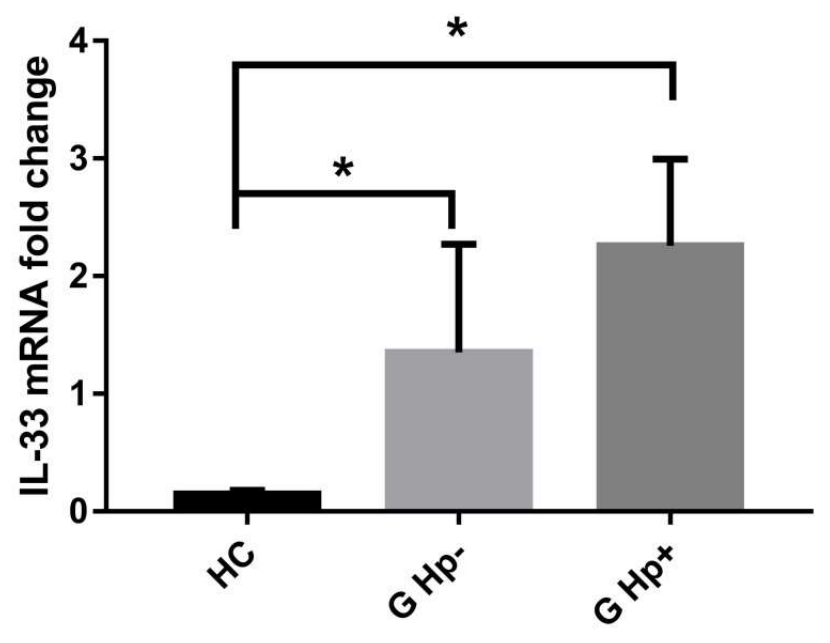


Figure 2: Proliferation assays. a) XTT, c) Wound healing and e) CFSE assays on GES-1 cells show an induction of proliferation after IL-33 treatment. The same assays on AGS (b, $d, f)$ show the opposite effect of IL-33 that can reduce proliferation. Data are shown as mean \pm sd. $\left.{ }^{*} p<0.05 ;{ }^{* *} p<0.01\right)$.
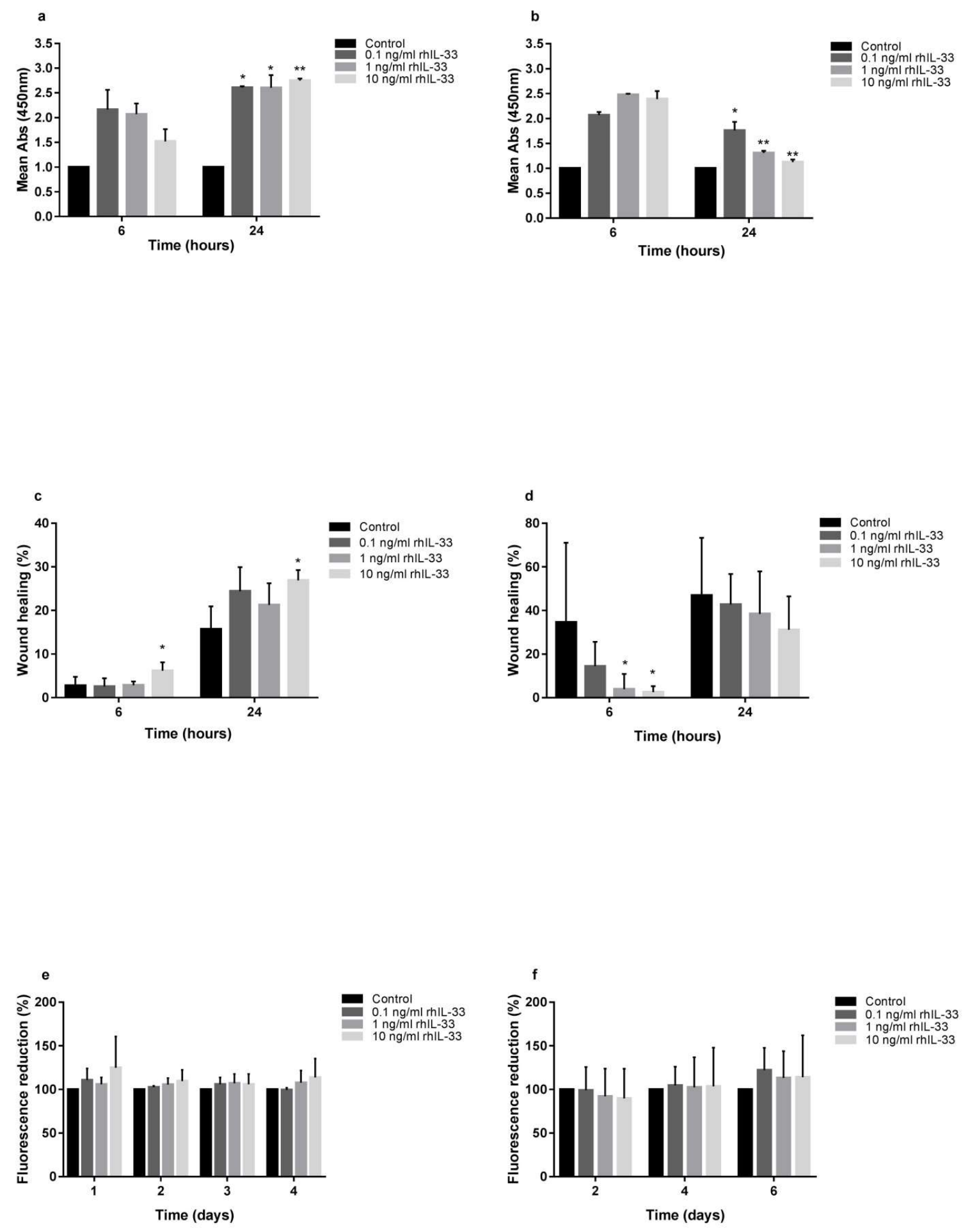
Figure 3: Apoptosis assays. a) Caspase 3/7 activity and (c) Annexin V/Propidium lodine assays show that IL33 can reduce apoptosis in GES-1 cells, while by means of the same assays on AGS (b, d) IL-33 can induce apoptosis. Data are shown as mean \pm sd. * $p<0.05$.
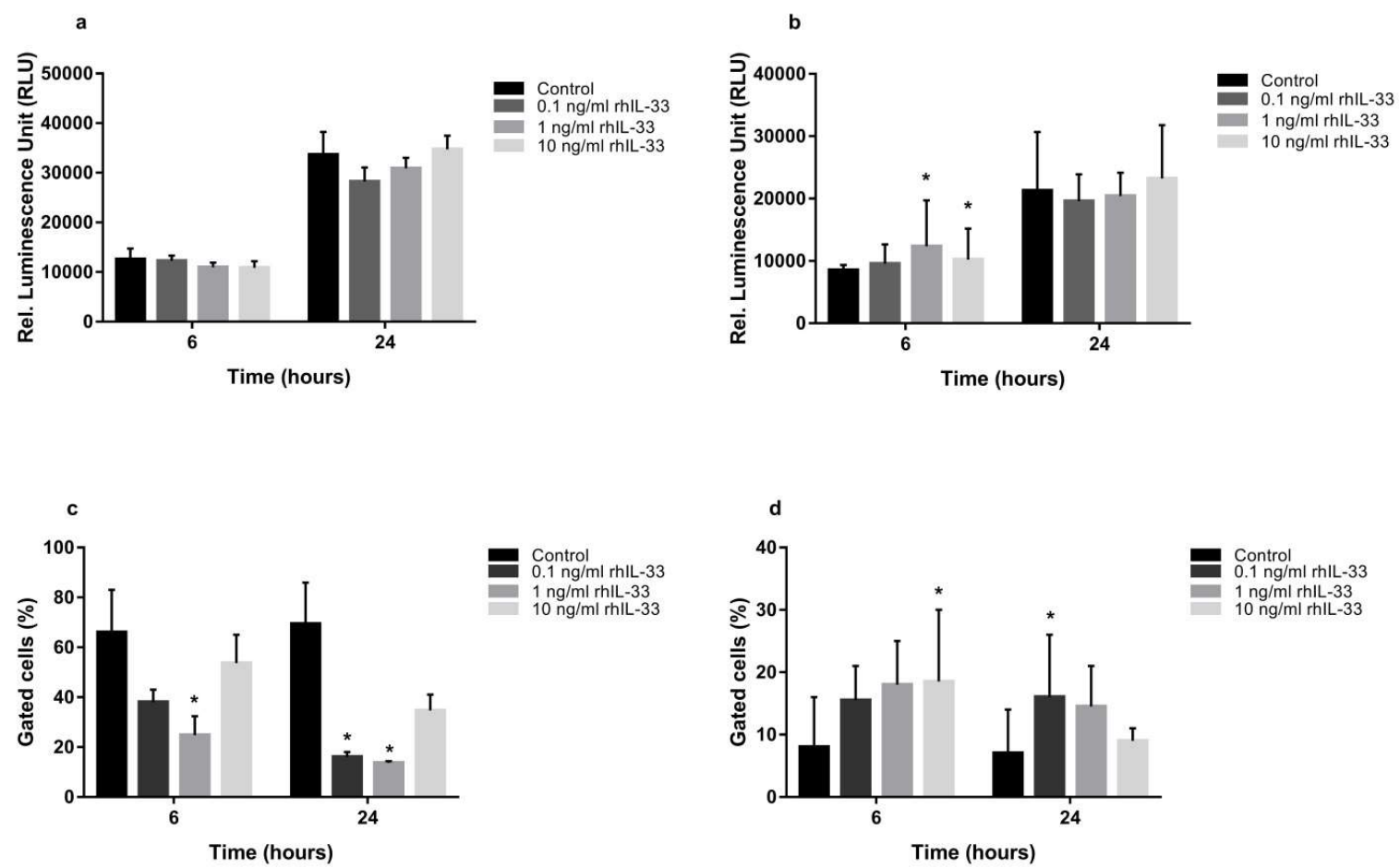
Figure 4: Cell cycle analysis by Propidium lodine staining. Cell cycle is impaired by IL-33 treatment in both cell lines. a) In GES-1 IL-33 induces an increase in phase $S$ at the expense of the other two, perhaps for a block between S phase and G2 phase; b) In AGS IL-33 seems to block cells between phases G1/G0 and S, and the latter decreases considerably after treatment at $24 \mathrm{~h}$. Data are shown as mean of $\%$ of gated cells.

a
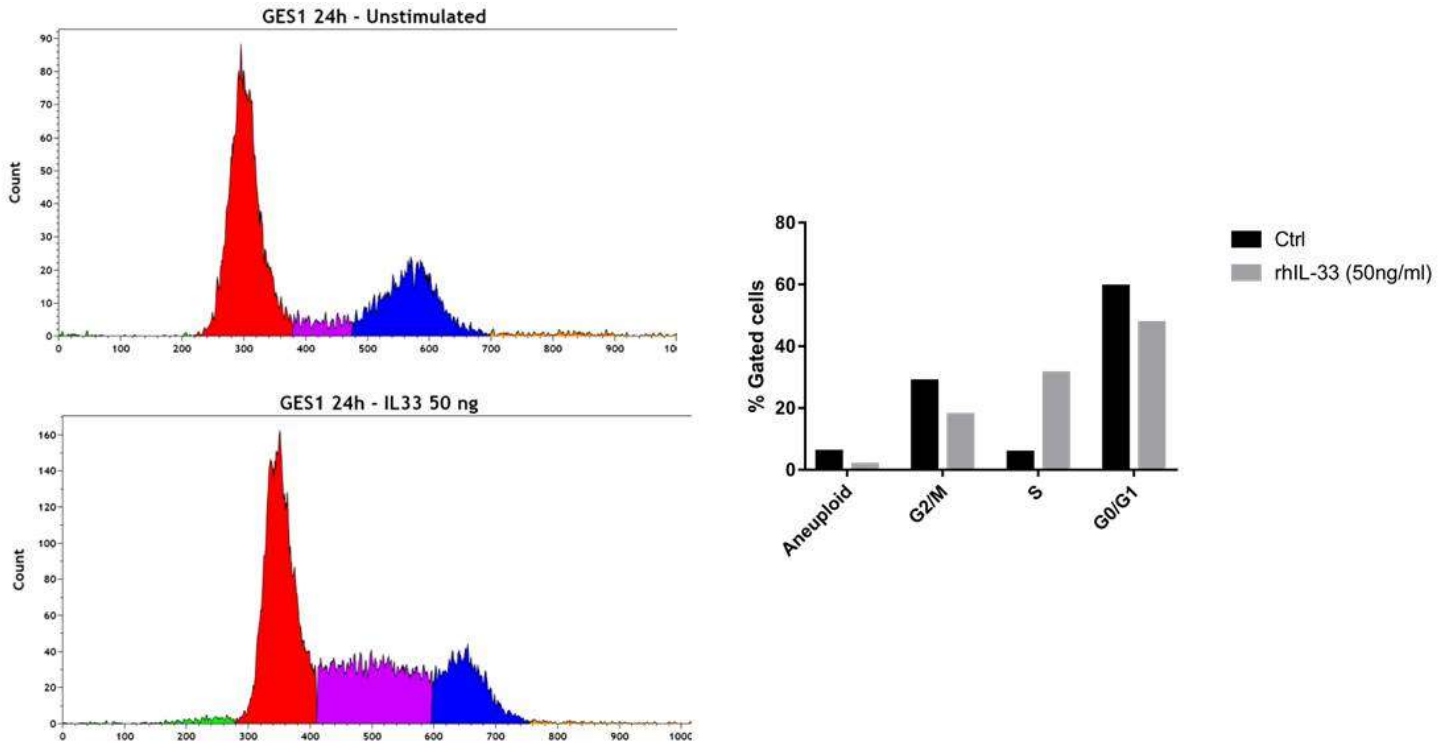

b
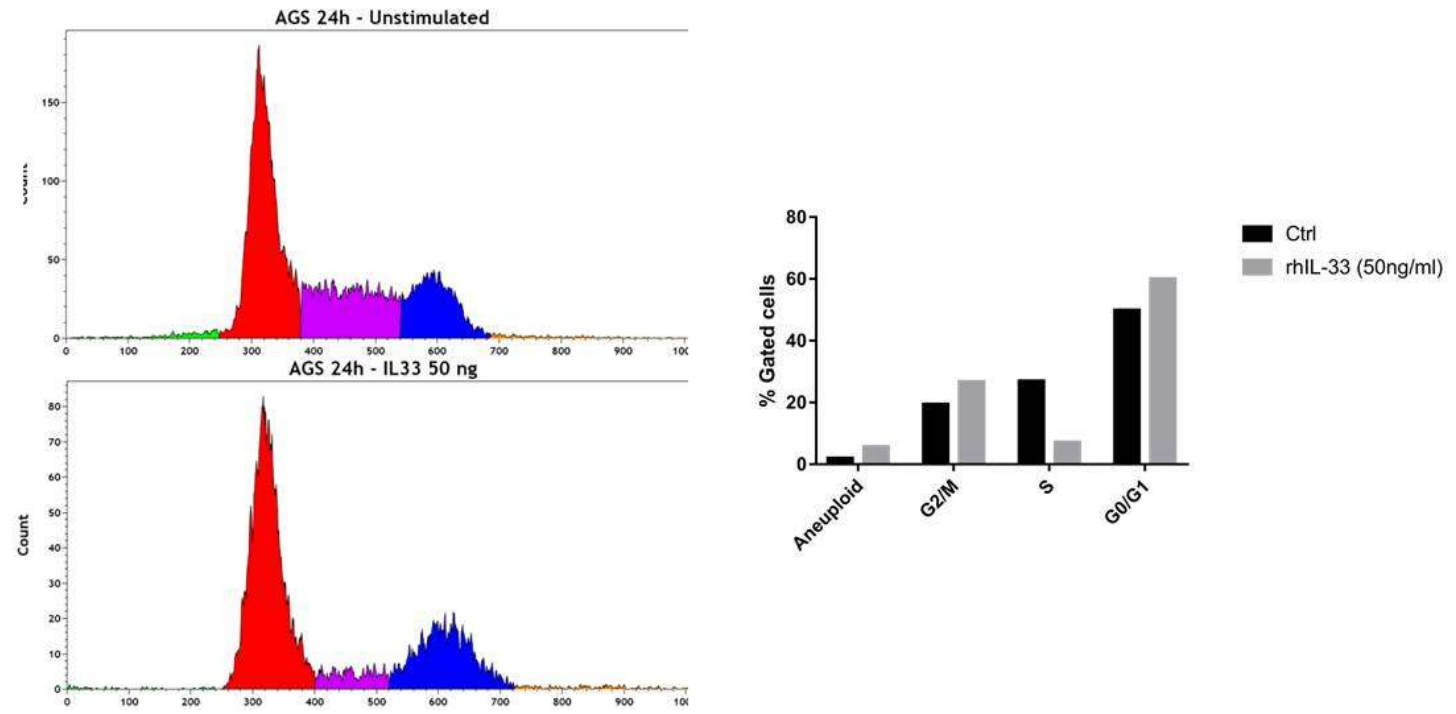
Figure 5: Expression of IL-33 and its receptor ST2 in gastric biopsies: a) IL-33 is downregulated in gastric cancer biopsies while b) its receptor ST2 is overexpressed in gastric cancer biopsies vs. healthy controls . Data are shown as mRNA Fold change \pm sd. HC: Healthy control; GC: Gastric cancer biopsies. ${ }^{*} p<0.05 ;{ }^{* *}$ $p<0.001$.

a

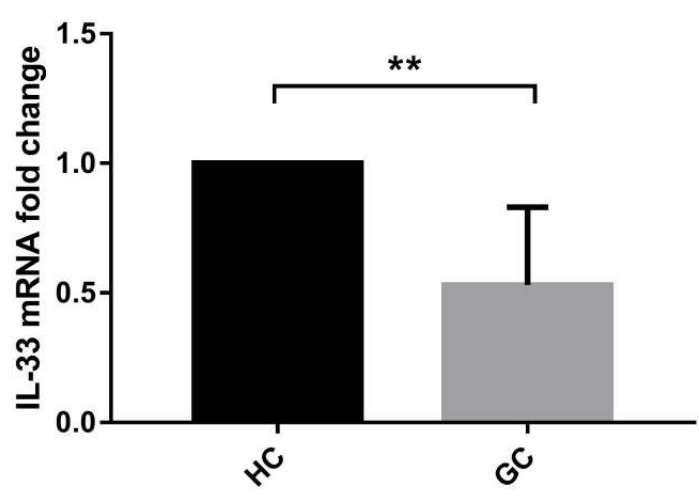

b

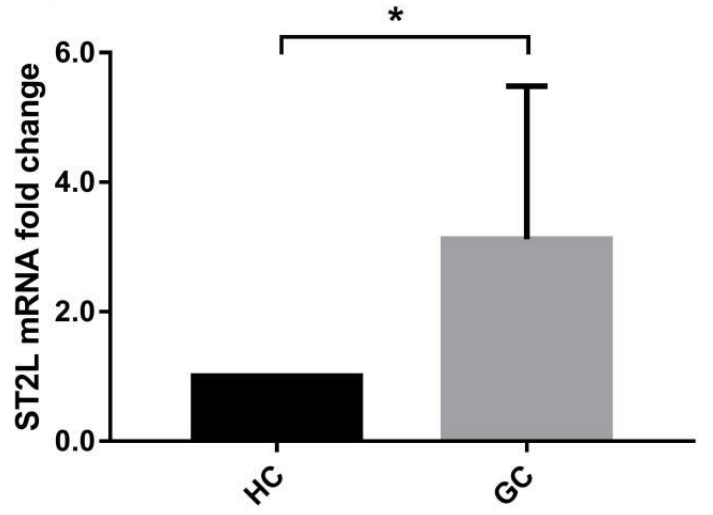


Figure 6: Gene expression in gastric biopsies. Cell cycle genes are overexpressed in gastric cancer biopsies vs. healthy controls. Data are shown as mRNA Fold change \pm sd. HC: Healthy control; GC: Gastric cancer biopsies. ${ }^{*} p<0.05$.

a

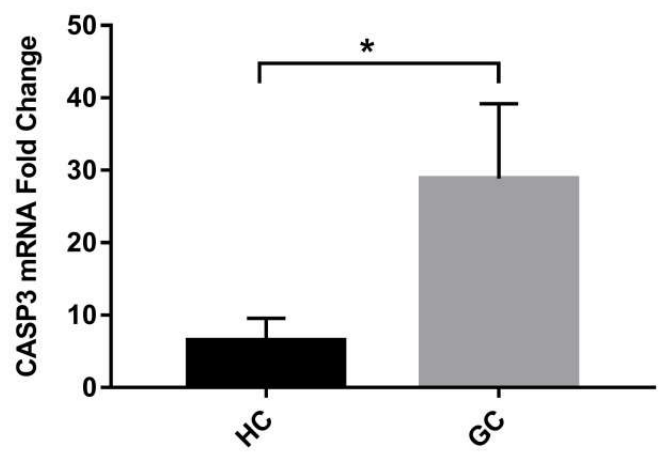

c

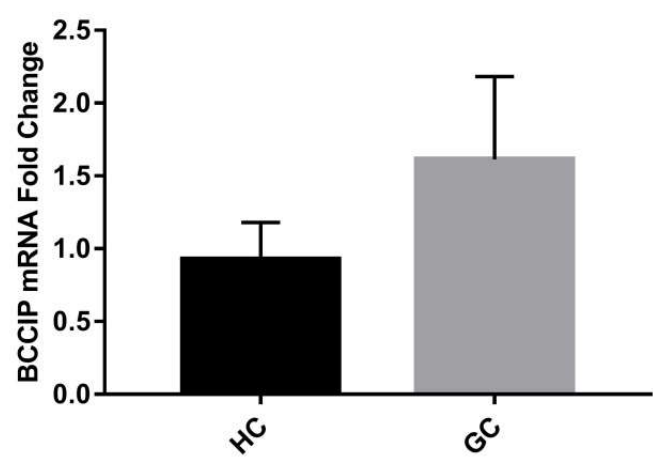

e

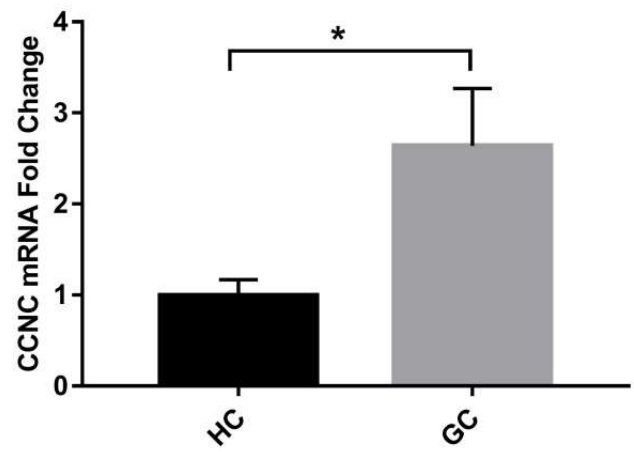

b

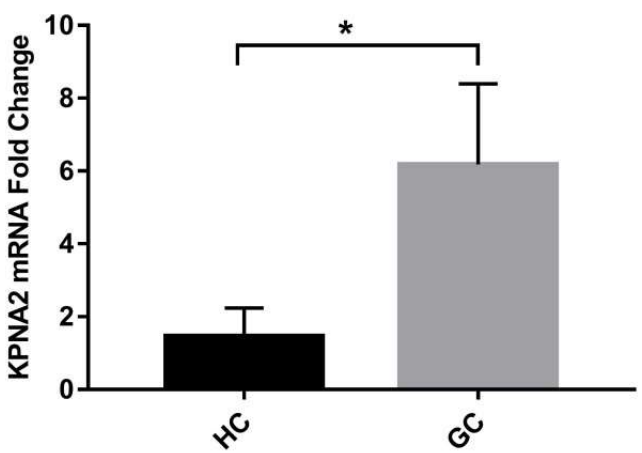

d

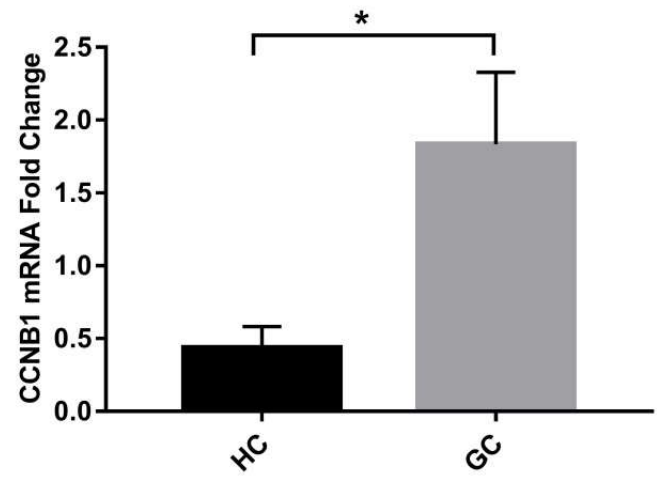

f

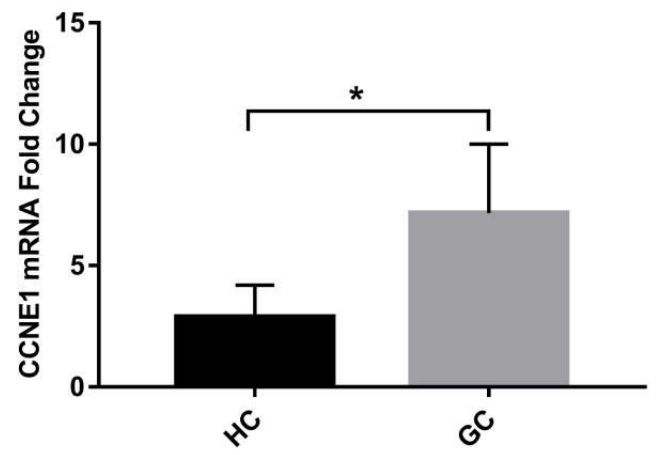


Figure 7: Gene expression in surgical specimen from gastric cancer patients with or without rhIL-33 treatment. Cell cycle genes are modulated both in $\mathrm{HC}$ and in gastric cancer after treatment with rhIL-33 for 48h. Data are shown as mRNA Fold change $\pm \mathrm{sd}$. HC: Healthy control; HC + rhIL-33: healthy control treated with rhIL-33; GC: Gastric cancer tissue; GC + rhIL-33: Gastric cancer tissue treated with rhIL-33. * $p<0.05$.

a

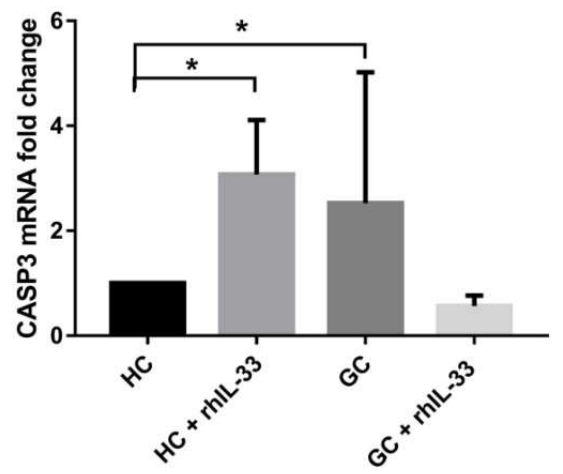

C

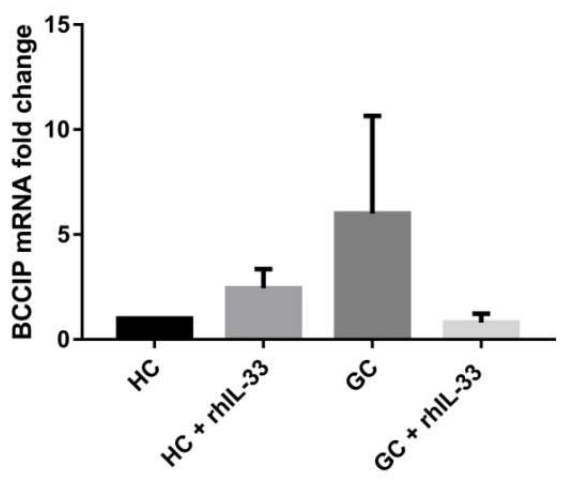

e

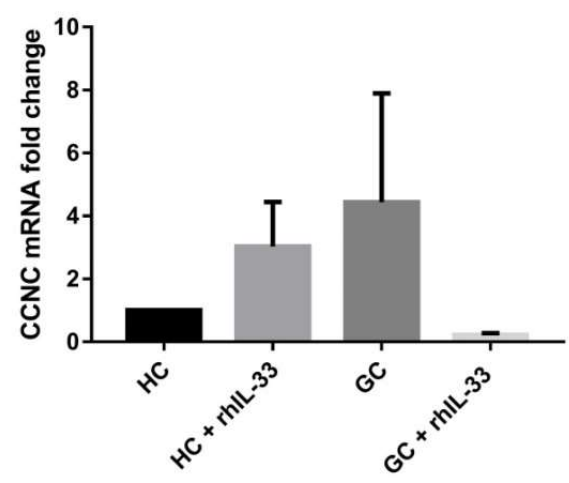

b

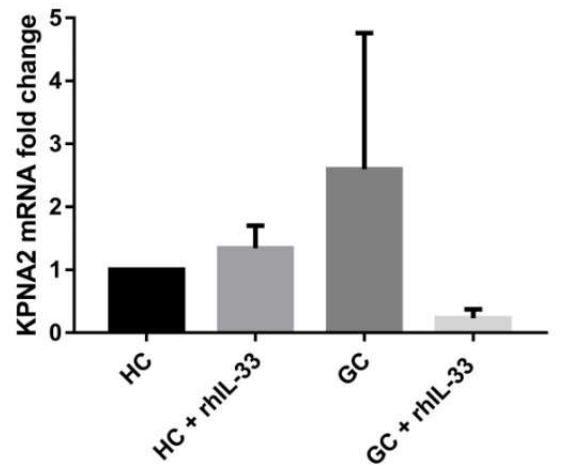

d

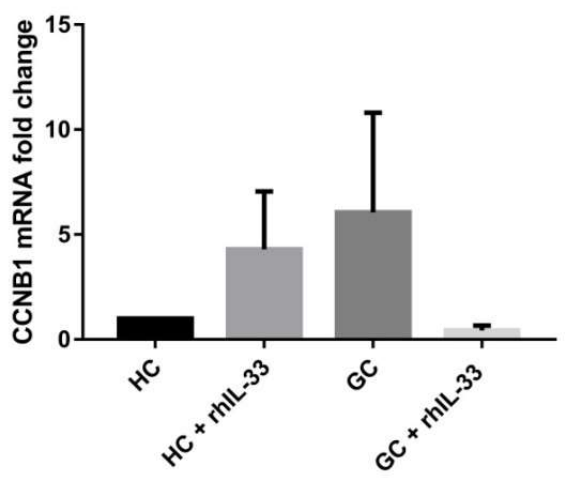

f

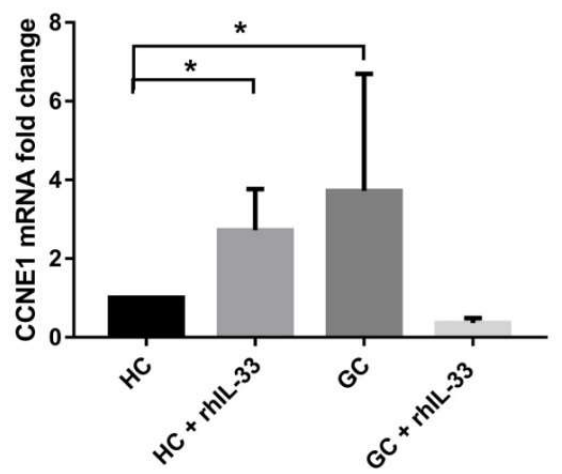


Figure 8: Schematic representation of cell cycles gene modulated by IL-33. a) in AGS IL-33 interact with gene which block G0/G1 transition and G2/M transition leading to a reduction of cell proliferation, while b) the induction of the overexpression of the same genes in GES-1 leads to an increase in proliferation.

a

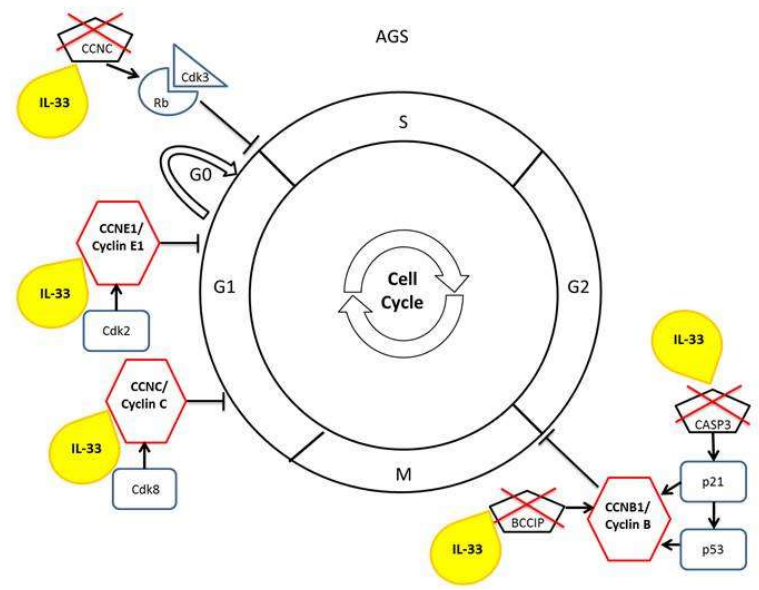

b

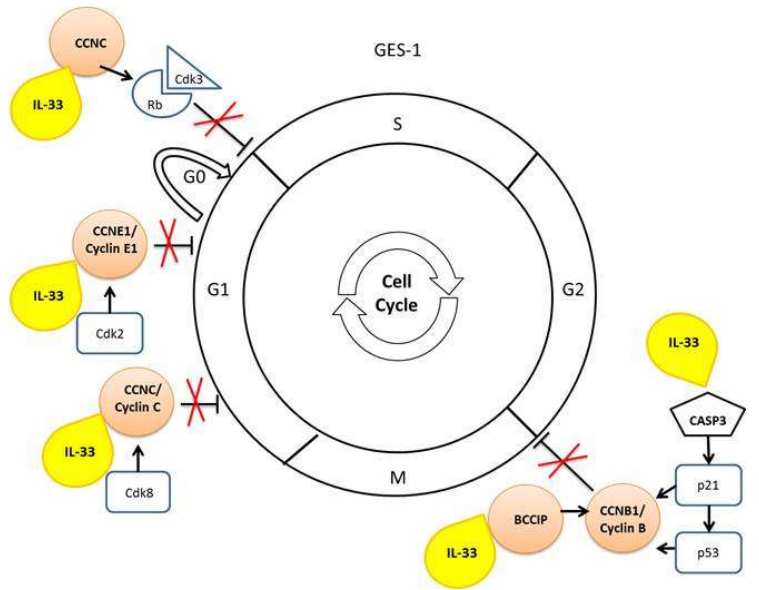


Supplementary Figure 1: Proliferation assays. a) XTT, b) Wound healing and c) CFSE assays on NCI-N87 cells show that IL-33 challenge of cells can reduce proliferation. Data are shown as mean \pm sd. ${ }^{*} p<0.05$.
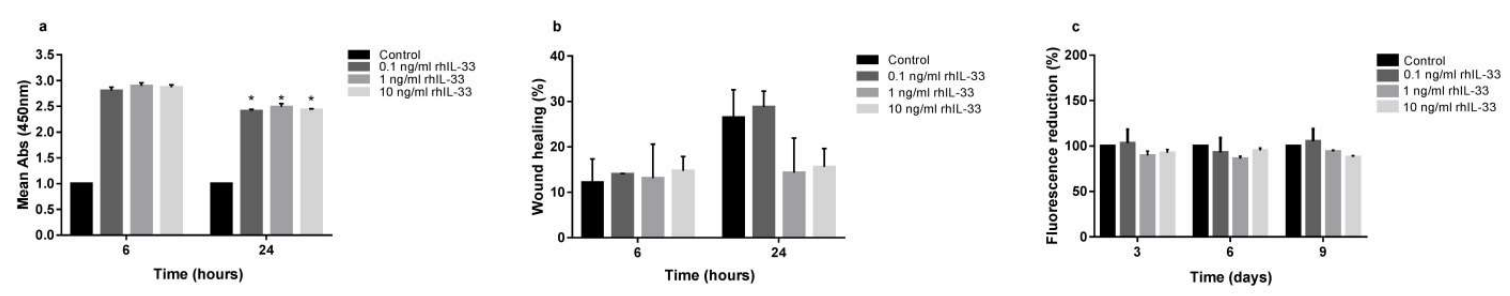

Supplementary Figure 2: Apoptosis assays. a) Caspase 3/7 activity and b) Annexin V/Propidium lodine assays show that IL-33 can induce apoptosis on NCI-N87 cell line. Data are shown as mean \pm sd. * $p<0.05$.
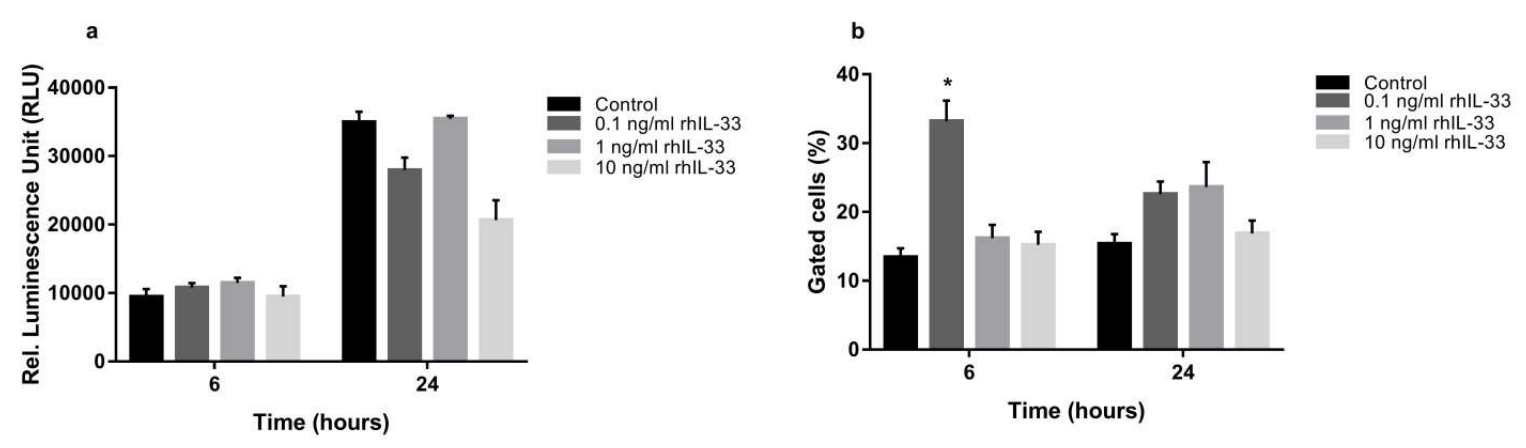